\title{
Management Perspectives of Electronic Data Interchange Systems
}

\author{
A. PICOT, R. NEUBURGER AND J. NIGGL
}

The authors are at the Institute of Organization, Seminar of Research in Information and Communication, Ludwig Maximilians University Munich, Ludwigstrasse 28, 8000 Munich 22, Germany.
'PICOT, A. AND REICHWALd, R. (1987). Bürokommunikation, Leitsätze für den Anwender, AIT, Hallbergmoos, pp. 3536.

\section{Interorganizational communication}

Interorganizational communication relates to the exchange of information between independent corporations or other organizations. This type of communication mainly deals with transactions for goods and services. In addition, interorganizational communication also covers the exchange of data in the field of research, development and manufacturing or the transfer of information to public authorities (e.g. customs).

More than 40 per cent of interorganizational communication is handled by the written media, in particular by documents that accompany business transactions. ${ }^{1}$ Such documents are mainly prepared, generated and processed by internal management information systems and by transaction-oriented systems. However, once they are electronically produced, they are printed and sent by mail to the addressee. On the receiver's side the document, once more, becomes an input into the computer system.

The main weaknesses of this kind of interorganizational communicating are: long transmission and lead times; high costs of administration; and increasing probability of errors. Overcoming such weaknesses is the main driving force for electronic data interchange systems. Direct communication between computer systems of the two organizations helps to exploit a considerable potential for increasing efficiency and improving competitiveness.

\section{The concept of electronic data interchange systems}

A crucial component of electronic data interchange systems is the exchange of commercial and technical data on the basis of standardized formats between computers of different organizations using electronic transmission and allowing for continuous, even online, processing. 


\begin{tabular}{|c|c|c|}
\hline $\begin{array}{l}\text { Inter- } \\
\text { industrial }\end{array}$ & $\begin{array}{l}\text { ANSI } \times .12 \\
\text { TRADACOMS }\end{array}$ & EDIFACT \\
\hline $\begin{array}{l}\text { Industry- } \\
\text { oriented }\end{array}$ & $\begin{array}{l}\text { VDA } \\
\text { SEDAS }\end{array}$ & $\begin{array}{l}\text { ODETTE } \\
\text { RINET } \\
\text { SWIFT }\end{array}$ \\
\hline
\end{tabular}

Figure 1. Standards in the environment of electronic data interchange systems. Abbreviations - ANSI X.12: American National Standards Institute X.12; TRADACOMS: Trading Data Communications Standards; VDA: Verband der Deutschen Automobilindustrie (Association of German Automobile Producers); SEDAS: Standardregelungen einheitlicher Datenaustausch-Systeme (Standard Rules of Uniform Data Interchange Systems); EDIFACT: Electronic Data Interchange for Administration, Commerce and Transport; ODETTE: Organization for Data Exchange by Teletransmission in Europe; RINET: Reinsurance and Insurance Network; SWIFT: Society for Worldwide Interbank Financial Telecommunication.

As interorganizational electronic communication interconnects, in many cases, hardware and software of different suppliers, the realization of such a concept is not at all trivial. The incompatibility of systems can only be overcome by mutual agreements on protocols and formats. Such agreements would be inefficient when many communication partners are involved, therefore the substitution of individual bilateral agreements by widely accepted standards is an efficient solution to the outlined problems.

However, reality does not support that picture. Today, a variety of standards has been developed, partly industry-oriented, partly restricted to national areas. Several standards have already reached some diffusion. They compete with an overall standard such as EDIFACT, which could serve as an inter-industry and international standard for electronic data interchange systems. The EDIFACT-standard has been initiated by the United Nations and was developed by the Economic Commission for Europe involving many national and supranational standardization institutions and other economic associations, ${ }^{2}$ as Figure 1 illustrates.

\section{Open communication on the basis of EDIFACT- standards}

The question today is not whether electronic data interchange systems can spread in the economic world - practical experience as well as research show a definite trend towards this new form of communication. ${ }^{3}$ The real problem is whether the existing specialized standards can be substituted by a comprehensive world standard. This

${ }^{2}$ VON MAAREN, H.C. (1989). The EDIFACT Standard, EDI-Forum, Journal of Electronic Data Interchange, 2, pp. 106-111.

${ }^{3}$ EDI-FORUM (1989). Journal of Electronic Data Interchange, 2; EDITORIAL (1990). ELEDIS Journal, pp. 1-5; HANSEN, J.V. AND HILL, N.C. (1989). Control and audit of electronic data interchange, MIS Quarterly, 13, pp. 403-413. kind of development is a precondition for worldwide, open interorganizational communication on a modern technical basis.

As the EDIFACT-standard was developed later than the specific standards, diffusion of EDIFACT is difficult. Once a network of communication partners has decided to adopt a special industry or national standard, changes become onerous. Switching costs as well as organizational adaptations inhibit a swift acceptance of a new, and presumably better, overall world standard. This can even be the case if a 


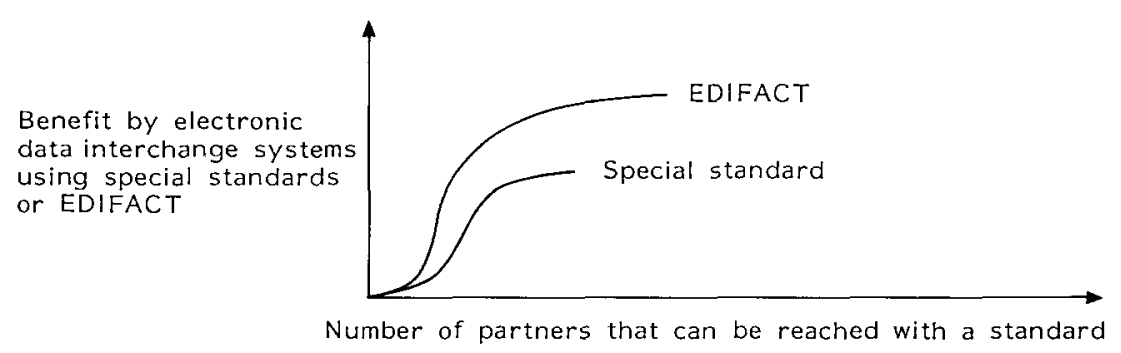

Figure 2. The benefits of electronic data interchange systems with respect to different standards

comprehensive switching to EDIFACT produces considerable additional benefits for a company.

Figure 2 shows the different prospects in terms of benefits that can be gained by specialized standards and by EDIFACT. The difference between EDIFACT and the specialized standards is due to the wider reach of EDIFACT, as it is possible to also reach partners in other industries and other countries, which increases the benefits of electronic data interchange systems.

The individual switching decision depends on the expectations about the probability of realizing additional benefits. These expectations coincide with the diffusion prospects. As the decision-maker cannot be sure that all the other partners will also shift to the new standard, it is a risk for him to invest in a new standard which might not allow him to reach all his partners. He will wait, therefore, for others to switch to the new standard before he makes the decision, even if his potential benefits are high.

This poses a dilemma: although a new standard would lead to higher benefits for all involved, switching from the old to the new standard does not take place ('excess inertia'). ${ }^{4}$ However, there are some possibilities for solving this problem: intensifying information and communication about this problem can lead to more switching decisions and to more trust with respect to the acceptance of the new standard. Conversion services can facilitate the move from one standard to another; professional and industrial associations can further the switching to the new standard. Public authorities as well as large companies can act as pioneers, thereby signalling to other organizations that the standard deserves trust and will spread. A recent decision of the Siemens corporation represents an example for the last point: Siemens has decided to use EDIFACT in external communication in logistics. A similar decision of the Bertelsmann corporation has been reported.

It must be mentioned that even under EDIFACT, a mutual agreement on message types used is necessary in order to start an effective electronic data interchange systems communication.

${ }^{4}$ FARRELl, J. AND SALONER, G. (1987). Competition, compatibility and standards: the economics of horses, penguins and lemmings, cited in Product Standardization and Competitive Strategy (L. Gabel, ed.), Elsevier Science Publishers B.V., Amsterdam, pp. 1-21.

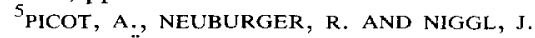
(1991). Ökonomische Perspektiveneines 'Electronic Data Interchange', Information Management, 5, pp. 22-29.

\section{Strategic and organizational consequences of electronic data interchange systems}

New dimensions of the accomplishment of tasks and transactions are the focus of the following considerations. ${ }^{5}$

\section{Open electronic communication}

As outlined above, electronic data interchange systems offer a con- 
tinuous processing of transactions and documents between organizations. Therefore the efficiency of internal and external communication patterns and of organizational processes will be increased. However, one has to keep in mind questions of data security and data protection. Such questions become important the more open electronic data interchange systems are designed.

\section{Disappearance of traditional functions}

Many manual functions and tasks that had to be fulfilled for traditional forms of interorganizational communication and intra-organizational processing are being substituted by electronic means (e.g. mail and postal services, checking of invoices, input of data).

\section{New requirements}

Electronic data interchange systems demand new forms of documentation, auditing and archives in order to cope with the new technical situation. As most transactions are directly related to accounting data and legal requirements, this aspect has to be dealt with thoroughly.

\section{New patterns of vertical integration}

The availability of rapid and powerful interorganizational electronic communication supports trends towards more vertical disintegration. Customers and suppliers, as well as other services, can fulfil functions that have so far been taken care of by the organization. Thus, the organization can focus its resources on strategically important core activities. ${ }^{6}$ This also leads to more network-type interorganizational patterns. $^{7}$

\section{Emergence of new ideas, strategies and business opportunities}

Electronic commercial transactions induce a generation of new entrepreneurial ideas. New patterns of vertical integration have already been mentioned. The interorganizational electronic communication infrastructure also facilitates strategic partnerships and alliances. Thus a selective exploitation of synergies for increased competitive advantages can be achieved without undergoing all the risks and inflexibilities that occur with full-scale mergers.

\section{Organizational consequences}

Electronic data interchange systems also help to create new services, such as value-added networks and new service concepts in logistics. ${ }^{8}$ As a consequence such new business opportunities, in conjunction with the earlier mentioned internal adaptations, change the way business pro-

${ }^{6}$ PICOT, A. (1991). Ein neuer Ansatz zur Gestaltung der Leistungstiefe, Zeitschrift für betriebswirtschaftliche Forschung, 43, pp. $336-357$.

For example, MLLES, R.E. AND SNOW, C.C. (1986). Network organizations: new concepts for new forms, McKinsey Quarterly, 10 , pp. 53-66.

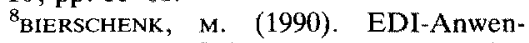
dungspraxis: VDA-ODETTE-EDIFACT, cited in $E D I 90$ by EWI Gesellschaft für Europäische Wirtschaftsinformatik $\mathrm{mbH}$, Starnberg, pp. 221-248. cesses are organized and managed:

- More process orientation in organizational design and management. Electronic data interchange systems integrate information flow and transactions between and within organizations. Thus, the traditional hierarchical orientation in the design of organizational structures has to step aside in favour of process orientation. The subsidiary function of hierarchy becomes clearer and an integrated and continuous business process becomes of paramount importance. This demands that staff and management gain new qualifications.

- New chances for modern concepts in logistics. A combination of 
A. Picot, R. Neuburger and J. Niggl

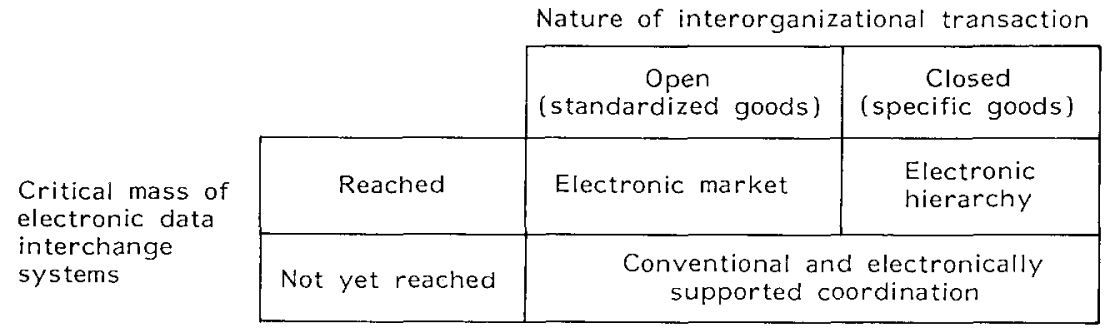

Figure 3. Coordination modes resulting from electronic data interchange systems (adapted from Hubmann, H.-E. (1989). Elektronisierung von Beschaffungsmärkten und Beschaffungshierarchien, VVF, München, p. 89)

electronic data interchange systems with just-in-time concepts offers new opportunities in logistics.

- Intensified integration with customers and suppliers. Integrated interorganizational communication, on the basis of electronic data interchange systems, changing patterns of vertical integration and new forms of interorganizational networking, calls for the adaptation of contractual arrangements as well as for new ways of social relations. Electronic data interchange systems not only demand a relational contract mode that covers the main principles of interorganizational commercial communication between the systems involved (data security, liability, crisis management, data protection, etc.) - the emerging new forms of interorganizational cooperation also demand more trusting relationships, less antagonism and the maintenance of a good atmosphere, so that real 'win-win'-partnerships can evolve.

- Electronic hierarchies and/or markets. Figure 3 shows the contingencies under which electronic data interchange systems create electronic markets or electronic hierarchies. Interorganizational relations develop towards an electronic hierarchy if specific goods are exchanged and a critical mass of electronic data interchange systems has been reached. In the case of specific goods, the relationship becomes to a certain extent exclusive and calls for a quasi-integration. On the other hand, electronic markets evolve if standardized goods are exchanged and if the critical mass of electronic data interchange systems has been reached. Thus, it depends on the character of the transactions involved whether electronic data interchange systems will further markets and their transparency or interorganizational integration and possible dependency. ${ }^{9}$

Electronic markets and electronic hierarchies both offer chances and risks. These have to be identified and taken into account. Electronic markets offer a quick and direct access to various information. They restrict opportunities for an exclusive and quasimonopolistic supply due to the increased transparency and standardization of the market. Electronic hierarchies, on the other hand,

${ }^{9}$ BENJAMIN, R.I., MALONE, T.W. AND YATES, J.A. (1986). Electronic Markets and Electronic Hierarchies: Effects of Information Technology on Market Structures and Corporate Strategies, Working Paper (90s:86-017), MIT, Cambridge, MA; нUBMANN, H.-E. (1989). Elektronisierung von Beschaffungsmärkten und Beschaffungshierarchien, VVF, München. demand clear judgement about the roles that the partners want to take (subordinate, superordinate or peer).

- Intensified competition. Electronic data interchange systems change the driving forces of competition - especially the role of time and speed increases. In the case of electronic hierarchies, the German situation teaches that under certain conditions between the supplier and manufacturer even the emergence of factual concerns (Faktischer Konzern) can be observed, which also influences the situation of 


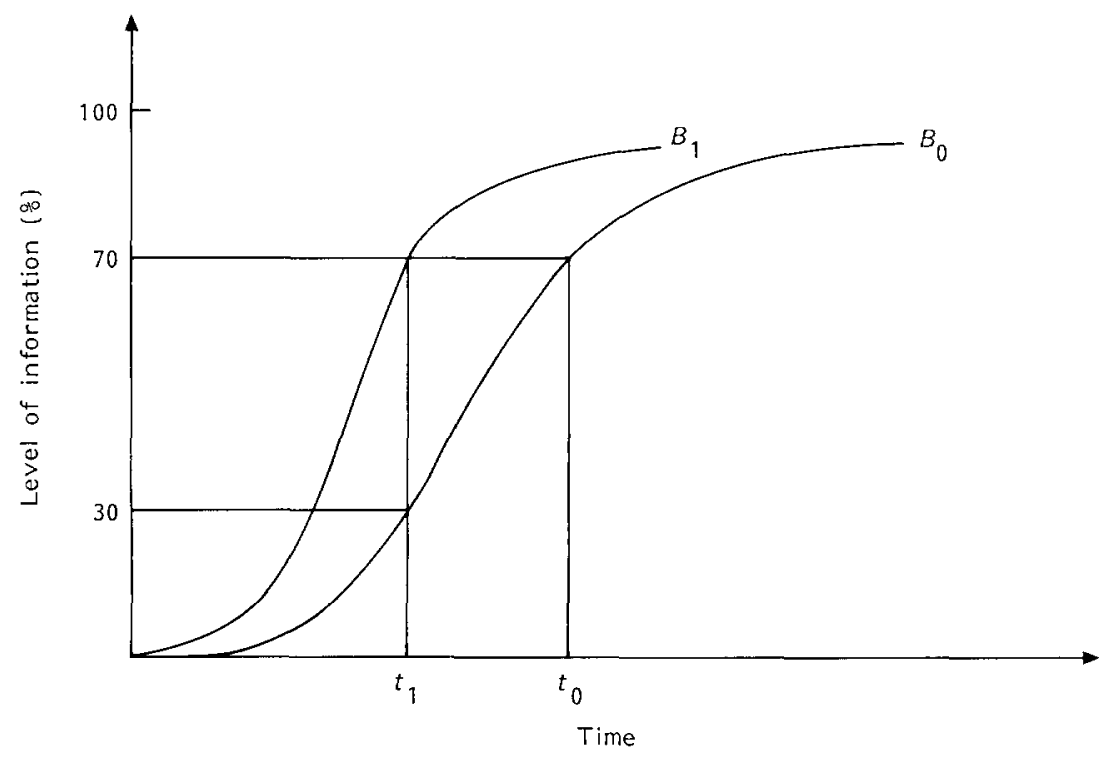

Figure 4. Decision time and level of information. $B_{0}$ : the traditional development of information level for a decision; $B_{1}$ : the necessary development of information level under new conditions

competition. ${ }^{10}$ Time as a factor in competition demands more flexibility and quicker reaction from all parties involved, especially management decision processes, which have to be adapted to the new environmental conditions (Figure 4). For example, if a company is used to making a certain decision (e.g. whether to engage in an offer or not) at an information level of 70 per cent, this can be reached by traditional information gathering and decision procedures $\left(B_{0}\right)$ at $t_{0}$. This decision time was sufficient in the past. However, the speedingup of interorganizational communication by electronic data interchange systems calls for a quicker reaction at $t_{1}$. If internal procedures were not changed, the company at $t_{0}$ would have reached an information level of only 30 per cent. This would mean that higher risks in decision-making would have to be taken. Therefore, under the new conditions, internal procedures must be developed so that at $t_{1}$ an information level of 70 per cent can be reached. This is symbolized by the slope $B_{1}$. Possible measures are: better access to internal and external databases; increasing the qualifications of personnel; integration of work organization; reduction of division of labour; and delegation of responsibilities.

${ }^{10}$ NAGEL, B., RIESS, B. AND THEIS, G. (1989). Der faktische Just-in-TimeKonzern - Unternehmensübergreifende Rationalisierungskonzepte und Konzernrecht am Beispiel der Automobilindustrie, Der Betrieb, 42, pp. 1505-1511; SCHEFFLER, E. (1990). Der qualifizierte faktische Konzern, Die Aktiengesellschaft, 34, pp. 173-178.

\section{Summary}

Electronic data interchange systems are not only technical devices used on the operational level of business transactions, but they imply considerable organizational as well as strategic challenges and chances that have to be taken into account by management in order to exploit the potential benefits of this infrastructural innovation. Cases, observations and practical experience in Europe as well as in North America prove that it is necessary to see the introduction of electronic data interchange systems as a management task that involves decision making and adaptations of the kind outlined above. 